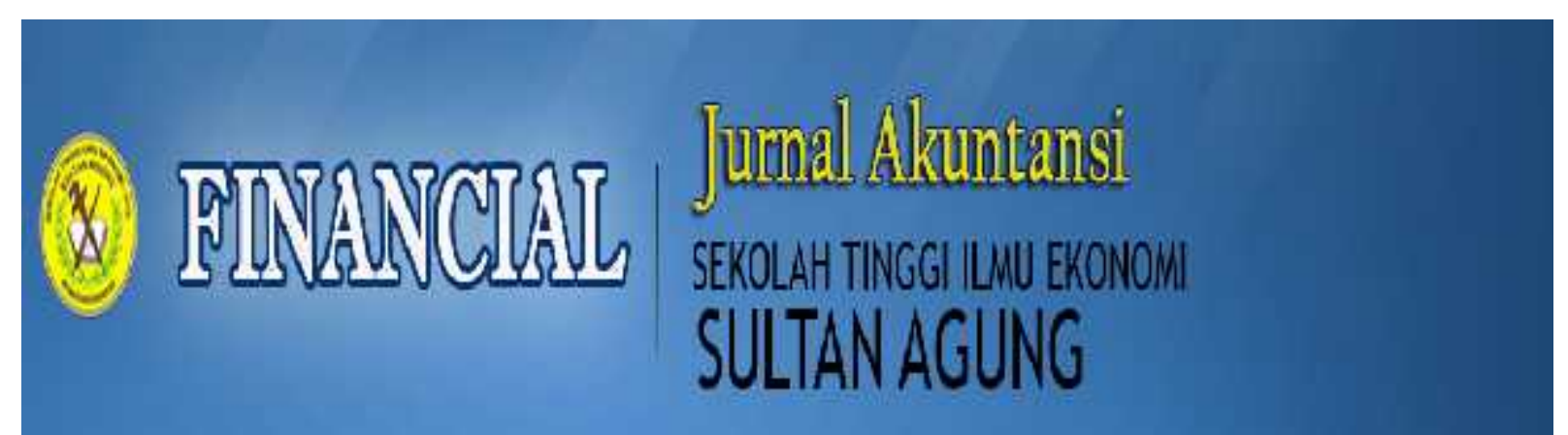

\title{
PENGARUH STRUKTUR MODAL, PROFITABILITAS DAN KEBIJAKAN DIVIDEN TERHADAP NILAI PERUSAHAAN PADA PERUSAHAAN SUB SEKTOR OTOMOTIF DAN KOMPONEN YANG TERDAFTAR DI BURSA EFEK INDONESIA
}

\author{
Oleh : \\ Pipit Ayu Kurniasih \\ S1 Akuntansi \\ Dr. Yansen Siahaan, Elly Susanti, Supitriyani
}

Abstrak

Tujuan dari penelitian ini adalah untuk mengetahui gambaran struktur modal, profitabilitas, kebijakan dividen dan nilai perusahaan serta pengaruh struktur modal, profitabilitas dan kebijakan dividen terhadap nilai perusahaan secara simultan maupun parsial pada Perusahaan Sub Sektor Otomotif dan Komponen yang Terdaftar di Bursa Efek Indonesia. Penelitian ini dilakukan dengan metode analisis deskriptif kualitatif dan analisis deskriptif kuantitatif. Objek penelitian ini adalah Sub Sektor Otomotif dan Komponen yang terdaftar di Bursa Efek Indonesia. Pengumpulan data digunakan metode dokumentasi. Teknik analisis yang digunakan adalah regresi linier berganda, koefisien korelasi, koefisien determinasi, uji F, uji t. Analisis data dengan menggunakan bantuan program SPSS versi 21.

Hasil penelitian dapat disimpulkan sebagai berikut: 1. Hasil pengujian diperoleh nilai rata-rata struktur modal dan profitabilitas mengalami fluktuasi dan cenderung menurunan. 2. Nilai rata-rata profitabilitas berfluktuasi dan cenderung menurun. 3. Nilai rata-rata kebijakan dividen berfluktuasi dan cenderung meningkat. 4. Nilai rata-rata nilai perusahaan pada berfluktuasi dan cenderung stabil. 5 . Hasil regresi linier berganda diperoleh struktur modal berpengaruh negatif sedangkan profitabilitas dan kebijakan dividen berpengaruh positif terhadap nilai perusahaan. 6 . Hasil pengujian koefisien korelasi dan determinasi terdapat korelasi yang sangat kuat antara nilai perusahaan dengan struktur modal, profitabilitas dan kebijakan dividen dan sisanya dipengaruhi oleh faktor lainnya. 7. Berdasarkan uji $F$, struktur modal, profitabilitas dan kebijakan dividen berpengaruh signifikan terhadap nilai perusahaan. Hasil uji t, struktur modal berpengaruh tidak signifikan sedangkan profitabilitas dan kebijakan dividen berpengaruh signifikan terhadap nilai perusahaan.

Hasil penelitian menyarankan perusahaan sebaiknya meningkatkan penggunaan struktur modal yang optimal serta meningkatkan penjualan agar memperoleh laba yang maksimal serta dapat membagikan dividen yang cukup tinggi kepada para investor dan harga saham dapat meningkat. Kata Kunci: Struktur Modal, Profitabilitas, Kebijakan Dividen dan Nilai perusahaan

Abstract

The purpose of this study are to know the description of capital structure, profitability, dividend policy and firm value and to determine the effect of capital structure, profitability, dividend policy on the value of the company in Sub Sector automotive and components listed on the Indonesia Stock Exchange either simultaneously or partially. This research was conducted by qualitative descriptive analysis method and quantitative descriptive analysis. The object of this study is the automotive and components Sub Sector listed on the stock exchange Indonesia. Data collection used documentation method. Analytical techniques used are multiple linear regression, correlation coefficient, coefficient of determination, $F$ test, $t$ test. Data analysis using SPSS version 21.

The result of the research can be summarized as follows: 1 . The test results obtained the average value of capital structure fluctuate and tend to decrease. 2. The average value of profitability fluctuates and tends to decrease. 3. The average value of dividend policy fluctuates and tends to increase. 4. The average value of the company's value fluctuates and tends to be stable. 5. The results of multiple linear regression obtained the capital structure have a negative effect while profitability and dividend policy have a positive effect on firm value. 6. The results of testing the correlation and determination coefficients have a very strong correlation between firm value and capital structure, profitability and dividend policy and the rest is influenced by other factors. 7. Based on the $F$ test, capital structure, profitability and dividend policy have a significant effect on company value. The results of the $t$ test, the capital structure has no significant effect while profitability and dividend policy have a significant effect on the value of the company

The results of the research suggest that companies should increase the optimal use of capital structure and increase sales in order to obtain maximum profits and can distribute dividends that are quite high to investors and stock prices can increase.

Keywords: Capital Structure, Profitability, Dividend Policy and FirmValue

Jurnal FINANCIAL

ISSN : 2502-4574 Vol. 4, No. 2, Desember 2018 


\section{PENDAHULUAN}

\subsection{Latar Belakang Masalah}

Nilai perusahaan merupakan salah satu ukuran keberhasilan manajemen perusahaan dalam operasi masa lalu dan prospek di masa yang akan datang dalam meyakinkan para pemegang saham. Nilai perusahaan dapat mencerminkan nilai asset yang dimiliki perusahaan, apabila semakin tinggi nilai perusahaan maka akan menciptakan penilaian yang semakin baik. Nilai perusahaan berkaitan dengan harga saham dikarenakan semakin tinggi harga saham maka akan semakin tinggi nilai perusahaan. Nilai perusahaan dapat diukur dari berbagai aspek, salah satunya adalah dengan menggunakan Price to Book Value (PBV). Price to Book Value merupakan perbandingan antara harga per saham dengan nilai buku per saham. Nilai buku per saham dapat dihitung sebagai hasil antara ekuitas dengan jumlah saham beredar.

Nilai perusahaan dapat dipengerahui oleh beberapa faktor salah satunya adalah struktur modal. Menurut Sudana (2011:164), "struktur modal adalah pembelanjaan jangka panjang suatu perusahaan yang diukur dengan perbandingan utang jangka panjang dengan modal sendiri". Struktur modal sangat penting bagi perusahaan karena berhubungan dengan besarnya risiko tingkat pengembalian atau tingkat keuntungan yang diharapkan.

Selain dipengaruhi oleh struktur modal, nilai perusahaan juga dipengaruhi oleh profitabilitas. Profitabilitas merupakan rasio untuk mengukur kemampuan perusahaan dalam memperoleh laba dan salah satu yang hal diperhatikan oleh para investor dan pemegang saham. Apabila suatu perusahaan mampu menghasilkan laba yang tinggi, maka harga saham juga dapat meningkat. Dalam penelitian ini penulis menggunakan Return On Equity (ROE) sebagai parameter pengukurannya.

Nilai perusahaan juga dapat dilihat dari kemampuan perusahaan dalam membayar dividen. Besar kecilnya dividen yang dibagi perusahaan dapat mempengaruhi harga saham. Apabila dividen yang yang dibagikan perusahaan semakin besar maka harga pasar saham perusahaan juga semakin tinggi begitu sebaliknya. Oleh karena itu dividen yang besar dapat meningkatkan nilai perusahaan. Dalam penelitian ini penulis menggunakan Dividend Payout Ratio (DPR) sebagai parameter pengukuran.

Berikut ini adalah gambaran Price to Book Value (PBV) pada Perusahaan Sub Sektor Otomotif dan Komponen yang terdaftar di Bursa Efek Indonesia periode 2011-2016.

Tabel 1.1

Gambaran Struktur Modal, Profitabilitas, Kebijakan Dlviden dan Nilai Perusahaan pada Perusahaan Sub Sektor Otomotif dan Komponen yang Terdaftar di Bursa Efek Indonesia Periode 2011-2016

\begin{tabular}{|c|c|c|c|c|}
\hline Tahun & $\begin{array}{c}\text { Struktu } \\
\text { r Modal }\end{array}$ & $\begin{array}{c}\text { Profita } \\
\text { bilitas }\end{array}$ & $\begin{array}{c}\text { Kebijak } \\
\text { an } \\
\text { Dividen }\end{array}$ & $\begin{array}{c}\text { Nilai } \\
\text { Perusa } \\
\text { haan }\end{array}$ \\
\hline 2011 & 0,254 & 0,279 & 0,387 & 2,190 \\
\hline 2012 & 0,246 & 0,263 & 0,472 & 4,207 \\
\hline 2013 & 0,186 & 0,223 & 0,455 & 3,750 \\
\hline 2014 & 0,149 & 0,215 & 0,438 & 4,054 \\
\hline 2015 & 0,179 & 0,159 & 0,470 & 2,947 \\
\hline 2016 & 0,139 & 0,165 & 0,495 & 2,710 \\
\hline $\begin{array}{c}\text { Rata- } \\
\text { rata }\end{array}$ & $\mathbf{0 , 1 9 2}$ & $\mathbf{0 , 2 1 7}$ & $\mathbf{0 , 4 5 3}$ & $\mathbf{3 , 3 1 0}$ \\
\hline
\end{tabular}

Sumber: Laporan Keuangan Perusahaan Sub Sektor Otomotif dan Komponen (Data Diolah)

Berdasarkan Tabel $1.1 \mathrm{di}$ atas dapat diketahui bahwa struktur modal dan profitabilitas mengalami fluktuasi dan cenderung menurun, kebijakan dividen mengalami fluktuasi dan cenderung meningkat sedangkan nilai perusahaan mengalami fluktuasi dan cenderung stabil pada Perusahaan Sub Sektor Otomotif dan 
Komponen yang terdaftar di Bursa Efek Indonesia periode 2011-2016.

\subsection{Rumusan Masalah}

1. Bagaimana gambaran struktur modal, profitabilitas, kebijakan dividen dan nilai perusahaan pada Perusahaan Sub Sektor Otomotif dan Komponen yang terdaftar di Bursa Efek Indonesia.

2. Bagaimana pengaruh struktur modal, profitabilitas dan kebijakan dividen terhadap nilai perusahaan pada Perusahaan Sub Sektor Otomotif dan Komponen yang terdaftar di Bursa Efek Indonesia baik secara simultan maupun parsial.

\subsection{Tujuan Penelitian}

1. Untuk mengetahui gambaran struktur modal, profitabilitas, kebijakan dividen dan nilai perusahaan pada Perusahaan Sub Sektor Otomotif dan Komponen yang terdaftar di Bursa Efek Indonesia.

2. Untuk mengetahui pengaruh struktur modal, profitabilitas dan kebijakan dividen terhadap nilai perusahaan pada Perusahaan Sub Sektor Otomotif dan Komponen yang terdaftar di Bursa Efek Indonesia baik secara simultan maupun parsial.

\subsection{Metode Penelitian}

Objek penelitian dari laporan keuangan Perusahaan Sub Sektor Otomotif dan Komponen yang Terdaftar di Bursa Efek Indonesia dari tahun 2011 sampai dengan 2016. Penelitian ini menggunakan data sekunder dengan mengakses website http://www.idx.co.id, www.sahamok.com, www.duniainvestasi.com.

Desain penelitian ini adalah penelitian kepustakaan (library research). Teknik analisa data yang digunakan adalah uji asumsi klasik, analisis deskriptif kualitatif dan analisis deskriptif kuantitatif.

\section{LANDASAN TEORI}

\subsection{Akuntansi}

Menurut Rudianto (2009:14), "akuntansi merupakan aktivitas mengumpulkan, menganalisis, menyajikan dalam bentuk angka, mengkasifikasikan, mencatat, meringkas, dan melaporkan aktivitas atau transaksi perusahaan dalam bentuk informasi keuangan". Menurut pendapat Mursyidi (2010:17), "akuntansi yaitu suatu proses pengidentifikasian data keuangan, memproses pengolahan serta penganalisisan data yang relevan dalam mengambil suatu keputusan".

Menurut Weygandt, Donald dan Paul (2007:4), "akuntansi (accounting) merupakan suatu sistem informasi yang mengidentifikasi, mencatat dan mengkomunikasikan peristiwa - peristiwa ekonomi dari suatu organisasi kepada para pengguna yang berkepentingan".

\subsection{Laporan Keuangan}

Menurut Martani, dkk (2012:62), "laporan keuangan merupakan informasi bagi penggunanya, terutama pemilik perusahaan, investor, kreditur, dan juga manajemen untuk mengambil keputusan-keputusan terkait perusahaan di masa mendatang".

Menurut Kieso, Jerry dan Terry (2007:2), "laporan keuangan merupakan sarana komunikasi dan informasi keuangan utama pihak - pihak diluar perusahaan". Sedangkan menurut Horngren dan Walter, (2007:17), "laporan keuangan adalah dokumen perusahaan yang melaporkan sebuah perusahaan dalam istilah moneter".

\subsection{Analisis Laporan Keuangan}

Menurut Rudianto (2009:190), "analisis laporan keuangan adalah meneliti hubungan yang ada di antara unsur-unsur dalam laporan keuangan, dan membandingkan unsur-unsur pada laporan keuangan tahun berjalan dengan unsur-unsur yang sama tahun lalu atau angka pembanding lain serta menjelaskan penyebab perubahannya". 
Sedangkan menurut Subramanyam dan John (2010:44), merupakan "suatu aplikasi dari alat dan teknik analisis bertujuan umum dan data - data yang berkaitan untuk menghasilkan prakiraan serta hasil yang bermanfaat.". Sedangkan menurut Astuti (2004:29), "analisis laporan keuangan adalah segala sesuatu yang menyangkut penggunaan informasi akuntansi untuk membuat keputusan bisnis dan investasi".

\subsection{Rasio Keuangan}

Menurut Astuti (2004:29), "rasio keuangan adalah penggunaan informasi akuntansi yang dirancang untuk membantu mengevaluasi laporan keuangan". Rasio keuangan didesain untuk memperlihatkan hubungan antara akun pada laporan keuangan (neraca dan laporan laba rugi).

Sedangkan rasio keuangan menurut Harahap (2015:297), yaitu "angka yang diperoleh dari hasil perbandingan antar laporan keuangan yang mempunyai hubungan relevan dan signifikan". Sedangkan menurut Kasmir (2010:93), "rasio keuangan merupakan kegiatan membandingkan angka-angka yang ada dalam laporan keuangan dengan cara membagi satu angka dengan angka lainnya".

\subsection{Struktur Modal}

Menurut Sudana (2011:164), "struktur modal adalah pembelanjaan jangka panjang suatu perusahaan yang diukur dengan perbandingan utang jangka panjang dengan modal sendiri". Sedangkan menurut Riyanto (2009:22), "struktur modal adalah pembelanjaan permanen dimana mencerminkan perimbangan antara utang jangka panjang dengan modal sendiri”.

Menurut Brigham dan Joel (2001:5), struktur modal optimal (optimal capital structure) "struktur modal perusahaan yang akan memaksimalkan harga sahamnya. Sasaran struktur modal (target capital structure) kombinasi utang, saham preferen dan ekuitas biasa yang akan menjadi dasar perhimpunan modal oleh perusahaan".

\subsection{Profitabilitas}

Menurut Astuti (2004:36), "rasio profitabilitas adalah kemampuan suatu perusahaan untuk menghasilkan laba". Sedangkan menurut Sudana (2011:25), "Profitability Ratio adalah rasio yang mengukur kemampuan perusahaan untuk menghasilkan laba dengan menggunakan sumber - sumber yang dimiliki perusahaan, seperti aktiva, modal atau penjualan perusahaan".

Menurut Brigham dan Joel (2010:146), "rasio profitabilitas adalah sekelompok rasio yang menunjukkan kombinasi dari pengaruh likuiditas, manajemen asset, dan utang pada hasil operasi”.

\subsection{Kebijakan Dividen}

Menurut Astuti (2004:145), "kebijakan dividen menyangkut keputusan untuk membagikan laba atau menahannya guna diinvestasikan kembali di dalam perusahaan". Keputusan apakah laba yang diperoleh perusahaan akan dibagikan kepada pemegang saham sebagai dividen atau ditahan dalam bentuk laba ditahan guna pembiayaan investasi dimasa yang akan datang.

Sedangkan kebijakan deviden menurut Brigham dan Joel (2010:66) yaitu, "kebijakan yang menciptakan keseimbangan di antara deviden saat ini dan pertumbuhan di masa mendatang yang memaksimumkan harga saham". Kemudian menurut Sudana (2011:167), "kebijakan dividen adalah besarnya persentase laba bersih setelah pajak yang dibagikan sebagai dividen kepada pemegang saham."

\subsection{Nilai Perusahaan}

Menurut Keown, et al (2004:470), yang dimaksud dengan "nilai perusahaan adalah nilai pasar atau surat berharga, hutang, dan ekuitas perusahaan yang beredar. Bagi para pemegang saham, harga pasar saham 
perusahaan menggambarkan nilai perusahaan termasuk seluruh kompleksitas dan resiko dunia nyata".

Menurut Brigham dan Joel (2010:151), "rasio harga pasar suatu saham terhadap nilai bukunya memberikan indikasi pandangan investor atas perusahaan. Perusahaan yang dipandang baik oleh investor adalah perusahaan dengan laba dan arus kas yang aman, serta terus mengalami pertumbuhan". Sedangkan, menurut Sudana (2011:8), "memaksimalkan nilai perusahaan berarti memaksimalkan nilai sekarang dari semua keuntungan yang akan diterima oleh pemegang saham dimasa yang akan datang atau berorientasi jangka panjang".

\subsection{Pengaruh Struktur Modal, Profitabilitas dan Kebijakan Dividen Terhadap Nilai Perusahaan}

Nilai Perusahaan dapat dipengaruhi oleh beberapa faktor, diantaranya yaitu struktur modal, profitabilitas dan kebijakan dividen. Menurut Sudana (2011:153), "berdasarkan signaling teory (teori sinyal), perusahaan yang mampu menghasilkan laba cenderung meningkatkan jumlah utangnya, karena tambahan bunga akan diimbangi dengan laba sebelum pajak". Kebijakan hutang yang dilakukan perusahaan menjadi salah satu pertimbangan para investor dalam mengambil keputusan investasi.

Profitabilitas menggambarkan kemampuan perusahaan dalam menghasilkan laba. Dalam penelitian ini pengukuran profitabilitas menggunakan return on equity (ROE). Rasio ini menunjukkan daya perusahaan untuk menghasilkan laba setelah pajak dengan menggunakan modal sendiri yang dimiliki perusahaan. Menurut Brigham dan Joel (2010:150), "jika rasio likuiditas, manajemen aset, manajemen utang dan profitabilitas semuanya terlihat baik dan apabila kondisi ini berjalan terus-menerus secara stabil maka rasio nilai pasar juga akan tinggi, harga saham kemungkinan tinggi sesuai dengan yang diperkirakan".

Selain karena profitabilitas, faktor yang mempengaruhi nilai perusahaan adalah kemampuan perusahaan untuk membayar dividen. Menurut Sudana (2011:167), "Teori Bird in-The-Hand yang dikemukakan oleh Myron Gordon dan John Lintner. Berdasarkan teori Bird in The Hand, kebijakan dividen berpengaruh positif terhadap harga saham". Artinya, apabila dividen yang dibagikan perusahaan semakin besar, harga pasar saham perusahaan tersebut akan semakin tinggi dan sebaliknya.

\section{ANALISIS DAN EVALUASI}

\subsection{Analisis}

\subsubsection{Analisis Deskriptif Kualitatif}

Analisis deskriptif dalam penelitian ini dimaksudkan untuk memperoleh gambaran atau deskriptif mengenai struktur modal, profitabilitas, kebijakan dividen dan nilai perusahaan pada perusahaan Sub Sektor Otomotif dan Komponen yang terdaftar di Bursa Efek Indonesia.

\subsubsection{Analisis Struktur Modal pada Perusahaan Sub Sektor Otomotif dan Komponen yang terdaftar di Bursa Efek Indonesia}

Struktur modal merupakan suatu pembelanjaan permanen kebutuhan perusahaan yang bersifat jangka panjang dengan perbandingan modal sendiri. Salah satu rasio yang digunakan untuk mengukur struktur modal adalah dengan Long term Debt to Equity Ratio (LtDER) untuk mengukur seberapa besar kecilnya penggunaan utang jangka panjang untuk membiayai aktivitas perusahaan. Semakin tinggi rasio ini mencerminkan semakin besar penggunaan ekuitas perusahaan dalam menjamin penggunaan utang jangka panjang sehingga resiko keuangan perusahaan semakin besar dan sebaliknya. Deskripsi nilai struktur modal pada Perusahaan Sub Sektor Otomotif dan Komponen yang 
terdaftar di Bursa Efek Indonesia periode 2011-2016 dapat dilihat pada Tabel 3.1.

Tabel 3.1

Deskripsi Nilai Struktur Modal pada Perusahaan Sub Sektor Otomotif dan Komponen yang Terdaftar di Bursa Efek Indonesia Periode 2011-2016

\begin{tabular}{|c|c|c|c|c|c|c|c|}
\hline $\begin{array}{c}\text { Kod } \\
\text { e } \\
\text { Emit } \\
\text { en }\end{array}$ & $\begin{array}{l}2011 \\
\text { (kali) }\end{array}$ & $\begin{array}{l}2012 \\
\text { (kali) }\end{array}$ & $\begin{array}{l}2013 \\
\text { (kali) }\end{array}$ & $\begin{array}{l}2014 \\
\text { (kali) }\end{array}$ & $\begin{array}{l}2015 \\
\text { (kali) }\end{array}$ & $\begin{array}{l}2016 \\
\text { (kali) }\end{array}$ & $\begin{array}{c}\text { Rata } \\
\text { - rata } \\
\text { (kali) }\end{array}$ \\
\hline ASII & $\begin{array}{l}0,38 \\
7\end{array}$ & $\begin{array}{c}0,42 \\
6\end{array}$ & $\begin{array}{c}0,34 \\
5\end{array}$ & $\begin{array}{c}0,35 \\
1\end{array}$ & $\begin{array}{c}0,33 \\
7\end{array}$ & $\begin{array}{c}0,23 \\
5\end{array}$ & 0,347 \\
\hline $\begin{array}{c}\text { AUT } \\
0\end{array}$ & $\begin{array}{l}0,07 \\
4 \\
\end{array}$ & $\begin{array}{c}0,11 \\
8 \\
\end{array}$ & $\begin{array}{c}0,04 \\
2 \\
\end{array}$ & $\begin{array}{c}0,03 \\
8 \\
\end{array}$ & $\begin{array}{c}0,05 \\
6 \\
\end{array}$ & $\begin{array}{c}0,07 \\
8 \\
\end{array}$ & 0,067 \\
\hline $\begin{array}{c}\text { SMS } \\
\mathbf{M}\end{array}$ & $\begin{array}{c}0,30 \\
0\end{array}$ & $\begin{array}{c}0,19 \\
3\end{array}$ & $\begin{array}{c}0,17 \\
0\end{array}$ & $\begin{array}{c}0,05 \\
7\end{array}$ & $\begin{array}{c}0,14 \\
5\end{array}$ & $\begin{array}{c}0,10 \\
5\end{array}$ & 0,162 \\
\hline $\begin{array}{l}\text { Rata } \\
\text {-rata }\end{array}$ & $\begin{array}{c}0,25 \\
4 \\
\end{array}$ & $\begin{array}{c}0,24 \\
6 \\
\end{array}$ & $\begin{array}{c}0,18 \\
6 \\
\end{array}$ & $\begin{array}{c}0,14 \\
9 \\
\end{array}$ & $\begin{array}{c}0,17 \\
9 \\
\end{array}$ & $\begin{array}{c}0,13 \\
9 \\
\end{array}$ & - \\
\hline \multicolumn{7}{|c|}{ Nilai LtDER Minimum (Kali) } & 0,038 \\
\hline \multicolumn{7}{|c|}{ Nilai LtDER Maksimum (Kali) } & 0,426 \\
\hline \multicolumn{7}{|c|}{ Rata - rata Keseluruhan (kali } & 0,1 \\
\hline
\end{tabular}

Sumber: Data Diolah

Berdasarkan Tabel 3.1, dapat diketahui bahwa nilai rata-rata struktur modal pada Perusahaan Sub Sektor Otomotif dan Komponen yang terdaftar di Bursa Efek Indonesia tahun 2011-2016 berfluktuasi dan cenderung mengalami penurunan. Hal ini disebabkan karena perusahaan lebih banyak menggunakan pendanaan dari pihak internal perusahaan dari pada pendanaan dari pihak eksternal perusahaan.

\subsubsection{Analisis Profitabilitas pada}

Perusahaan Sub Sektor Otomotif dan Komponen yang Terdaftar di Bursa Efek Indonesia

Profitabilitas menunjukkan tingkat kemampuan perusahaan dalam menghasilkan laba atas pengelolaan aset perusahaan dalam hubungannya dengan penjualan, total aktiva dan modal sendiri. Profitabilitas dalam penelitian ini diukur dengan menggunakan Return on Equity (ROE). Rasio ini menunjukkan kemampuan perusahaan untuk menghasilkan laba setelah pajak dengan menggunakan total ekuitas yang dimiliki perusahaan. Deskripsi nilai struktur modal pada Perusahaan Sub Sektor Otomotif dan Komponen yang terdaftar di Bursa Efek Indonesia periode 2011-2016 dapat dilihat pada Tabel 3.2.

Tabel 3.2

Deskripsi Nilai Profitabilitas pada Perusahaan Sub Sektor Otomotif dan Komponen yang Terdaftar di Bursa Efek Indonesia Periode 2011-2016

\begin{tabular}{|c|c|c|c|c|c|c|c|}
\hline $\begin{array}{l}\text { Kode } \\
\text { Emiten }\end{array}$ & $\begin{array}{l}2011 \\
\text { (kali) }\end{array}$ & $\begin{array}{l}2012 \\
\text { (kali) }\end{array}$ & $\begin{array}{l}2013 \\
\text { (kali) }\end{array}$ & $\begin{array}{l}2014 \\
\text { (kali) }\end{array}$ & $\begin{array}{l}2015 \\
\text { (kali) }\end{array}$ & $\begin{array}{l}2016 \\
\text { (kali) }\end{array}$ & $\begin{array}{l}\text { Rata } \\
\text { - rata } \\
\text { (kali) }\end{array}$ \\
\hline ASII & 0,278 & 0,253 & 0,210 & 0,184 & 0,123 & 0,131 & 0,197 \\
\hline AUTO & 0,233 & 0,207 & 0,111 & 0,094 & 0,032 & 0,046 & 0,103 \\
\hline SMSM & 0,327 & 0,327 & 0,348 & 0,368 & 0,320 & 0,318 & 0,287 \\
\hline $\begin{array}{c}\text { Rata- } \\
\text { rata }\end{array}$ & 0,279 & 0,263 & 0,223 & 0,215 & 0,159 & 0,165 & - \\
\hline \multicolumn{7}{|c|}{ Nilai ROE Minimum (Kali) } & 0,032 \\
\hline \multicolumn{7}{|c|}{ Nilai ROE Maksimum (Kali) } & 0,368 \\
\hline \multicolumn{7}{|c|}{ Rata-rata keseluruhan (Kali) } & 0,196 \\
\hline
\end{tabular}

Sumber: Data Diolah

Berdasarkan Tabel 3.2 menunjukkan rata - rata profitabilitas pada perusahaan Sub Sektor Otomotif dan Komponen yang terdaftar di Bursa Efek Indonesia periode 2011 - 2016 berfluktuasi dan cenderung menurun. Hal ini disebabkan karena lebih besarnya laba bersih setelah pajak yang digunakan dibandingkan dengan total ekuitas perusahaan.

\subsubsection{Analisis Kebijakan Dividen pada Perusahaan Sub Sektor Otomotif dan Komponen yang Terdaftar di Bursa Efek Indonesia Periode 2013-2017 \\ Kebijakan dividen merupakan suatu} kebijakan mengenai keputusan yang diambil oleh perusahaan tentang bagaimana tingkat laba yang diperoleh perusahaan akan dibagikan kepada pemegang saham sebagai dividen atau ditahan dalam dalam bentuk laba ditahan yang digunakan untuk membiayai investasi perusahaan dimasa akan datang. Dalam penelitian ini, penulis menggunakan rasio Dividen Payout Ratio 
(DPR) untuk mengukur kebijakan dividen perusahaan. Rasio pembayaran dividen (DPR) menunjukkan rasio dividen yang dibagikan perusahaan dengan laba bersih yang dihasilkan perusahaan.Deskripsi nilai struktur modal pada Perusahaan Sub Sektor Otomotif dan Komponen yang terdaftar di Bursa Efek Indonesia periode 2011-2016 dapat dilihat pada Tabel 3.3.

Tabel 3.3

Deskripsi Nilai Kebijakan Dividen pada

Perusahaan Sub Sektor Otomotif dan

Komponen yang Terdaftar di Bursa Efek Indonesia Periode 2011-2016

\begin{tabular}{|c|c|c|c|c|c|c|c|}
\hline $\begin{array}{l}\text { Kode } \\
\text { Emiten }\end{array}$ & $\begin{array}{l}2011 \\
\text { (kali) }\end{array}$ & $\begin{array}{l}2012 \\
\text { (kali) }\end{array}$ & $\begin{array}{l}2013 \\
\text { (kali) }\end{array}$ & $\begin{array}{l}2014 \\
\text { (kali) }\end{array}$ & $\begin{array}{l}2015 \\
\text { (kali) }\end{array}$ & $\begin{array}{l}2016 \\
\text { (kali) }\end{array}$ & $\begin{array}{c}\text { Rata } \\
\text { - rata } \\
\text { (kali) }\end{array}$ \\
\hline ASII & 0,045 & 0,450 & 0,450 & 0,456 & 0,496 & 0,449 & 0,391 \\
\hline AUTO & 0,402 & 0,319 & 0,376 & 0,398 & 0,409 & 0,402 & 0,384 \\
\hline SMSM & 0,714 & 0,648 & 0,537 & 0,461 & 0,505 & 0,633 & 0,583 \\
\hline $\begin{array}{c}\text { Rata- } \\
\text { rata }\end{array}$ & 0,387 & 0,472 & 0,455 & 0,438 & 0,470 & 0,495 & - \\
\hline \multicolumn{7}{|c|}{ Nilai DPR Minimum (kali) } & 0,045 \\
\hline \multicolumn{7}{|c|}{ Nilai DPR Maksimum (kali) } & 0,714 \\
\hline \multicolumn{7}{|c|}{ Rata - rata keseluruhan (kali) } & 0,453 \\
\hline
\end{tabular}

Sumber: Data Diolah

Berdasarkan

Tabel

3.3

menunjukkan rata - rata kebijakan dividen pada perusahaan Sub Sektor Otomotif dan Komponen yang terdaftar di Bursa Efek Indonesia periode 2011 - 2016 berfluktuasi dan cenderung meningkat. Hal ini disebabkan oleh laba per lembar saham dan dividen sama - sama mengalami penurunan, akan tetapi penurunan laba per lembar saham lebih besar dibandingkan dividen.

\subsubsection{Analisis Nilai Perusahaan pada} Perusahaan Sub Sektor Otomotif dan Komponen yang Terdaftar di Bursa Efek Indonesia Periode 2013-2017

Meningkatkan nilai perusahaan sangat penting artinya bagi suatu perusahaan, karena dengan meningkatkan nilai perusahaan berarti juga dapat meningkatkan kemakmuran pemegang saham. Menurut Brigham dan Joel (2010:151), "rasio harga pasar suatu saham terhadap nilai bukunya memberikan indikasi pandangan investor atas perusahaan. Perusahaan yang dipandang baik oleh investor adalah perusahaan dengan laba dan arus kas yang aman, serta terus mengalami pertumbuhan". Dalam penelitian ini, untuk mengukur nilai perusahaan penulis menggunakan Price to Book Value (PBV), rasio ini dapat menjelaskan perbandingan antara harga pasar saham dengan nilai buku saham. Deskripsi nilai struktur modal pada Perusahaan Sub Sektor Otomotif dan Komponen yang terdaftar di Bursa Efek Indonesia periode 2011-2016 dapat dilihat pada Tabel 3.4.

Tabel 3.4

Deskripsi Nilai Perusahaan pada Perusahaan Sub Sektor Otomotif dan Komponen yang Terdaftar di Bursa Efek Indonesia Periode 2011-2016

\begin{tabular}{|c|c|c|c|c|c|c|c|}
\hline $\begin{array}{c}\text { Kode } \\
\text { Emiten }\end{array}$ & $\begin{array}{c}\mathbf{2 0 1 1} \\
\text { (kali) }\end{array}$ & $\begin{array}{c}\mathbf{2 0 1 2} \\
\text { (kali) }\end{array}$ & $\begin{array}{c}\mathbf{2 0 1 3} \\
\text { (kali) }\end{array}$ & $\begin{array}{c}\mathbf{2 0 1 4} \\
\text { (kali) }\end{array}$ & $\begin{array}{c}\mathbf{2 0 1 5} \\
\text { (kali) }\end{array}$ & $\begin{array}{c}\mathbf{2 0 1 6} \\
\text { (kali) }\end{array}$ & $\begin{array}{c}\text { Rata } \\
\text { Rata } \\
\text { (kali) }\end{array}$ \\
\hline ASII & 0,496 & 4,321 & 3,280 & 3,144 & 2,380 & 2,992 & 2,769 \\
\hline Auto & 2,842 & 2,666 & 2,041 & 2,214 & 0,841 & 1,041 & 1,941 \\
\hline SMSM & 3,232 & 5,634 & 5,930 & 6,804 & 5,618 & 4,096 & 5,219 \\
\hline $\begin{array}{c}\text { Rata - } \\
\text { Rata }\end{array}$ & $\mathbf{2 , 1 9 0}$ & $\mathbf{4 , 2 0 7}$ & $\mathbf{3 , 7 5 0}$ & $\mathbf{4 , 0 5 4}$ & $\mathbf{2 , 9 4 7}$ & $\mathbf{2 , 7 1 0}$ & - \\
\hline \multicolumn{7}{|c|}{ Nilai PBV Minimum (kali) } & $\mathbf{0 , 4 9 6}$ \\
\hline \multicolumn{7}{|c|}{ Rata - rata keseluruhan (kali) } & $\mathbf{6 , 8 0 4}$ \\
\hline \multicolumn{7}{|c|}{}
\end{tabular}

Sumber: Data Diolah

Berdasarkan Tabel 3.4 menunjukkan bahwa nilai rata-rata nilai perusahaan pada Perusahaan Sub Sektor Otomotif dan Komponen yang terdaftar di Bursa Efek Indonesia periode 2011-2016 berfluktuasi dan cenderung stabil. Hal ini disebabkan karena nilai buku per lembar saham yang meningkat diikuti dengan peningkatan harga saham. Hal ini dapat dilihat nilai perusahaan pada tahun 2011 adalah sebesar 2,190 sedangkan nilai perusahaan pada tahun 
2016 adalah sebesar 2,710. Nilai perusahaan yang stabil disebabkan oleh meningkatnya harga saham dan nilai buku tidak terlalu tinggi.

\subsubsection{Analisis Deskriptif Kuantitatif} 3.1.2.1. Analisis Regresi Linear Berganda Analisis regresi linier berganda digunakan untuk menganalisis hubungan antara variabel independen terdapat variabel dependen. Persamaan regresi linier berganda dapat dilihat pada Tabel 3.5.

Tabel 3.5

Hasil Analisis Regresi Linier Berganda

\begin{tabular}{|l|r|r|r|}
\hline Model & \multicolumn{2}{|c|}{$\begin{array}{c}\text { Unstandardized } \\
\text { Coefficients }\end{array}$} & \multicolumn{2}{|c|}{$\begin{array}{c}\text { Standardized } \\
\text { Coefficients }\end{array}$} \\
\cline { 2 - 4 } & \multicolumn{1}{|c|}{ B } & $\begin{array}{c}\text { Std. } \\
\text { Error }\end{array}$ & \multicolumn{2}{|c|}{ Beta } \\
\hline (Consta &,- 675 &, 938 & \\
nt) & & 1,946 &,- 157 \\
LtDER & $-2,127$ &, 686 \\
ROE & 11,459 & 2,553 &, 336 \\
DPR & 4,206 & 1,878 & \\
\hline
\end{tabular}

Sumber : Hasil Pengolahan Data (SPSS 21

Berdasarkan hasil analisis regresi pada Tabel 3.5 , maka dapat model regresi adalah sebagai berikut:

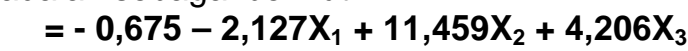

Dari hasil persamaan tersebut, dapat disimpulkan bahwa struktur modal berpengaruh negatif sedangkan profitabilitas dan kebijakan dividen berpengaruh positif terhadap nilai perusahaan pada Perusahaan Sub Sektor Otomotif dan Komponen yang terdaftar di Bursa Efek Indonesia periode $2011-2016$.

\subsubsection{Koefisien \\ Determinasi}

Korelasi

dan

Nilai koefisien korelasi $(r)$ digunakan untuk menunjukkan seberapa besar korelasi atau hubungan antara variabel-variabel independen dengan variabel dependen. Sementara koefisien determinasi menunjukkan kemampuan variabel independen menjelaskan variasi perubahan pada variabel dependennya. Berikut hasil pengolahan data yang menunjukkan koefisien korelasi dan determinasi.

Tabel 3.6

Analisis Koefisien Korelasi dan Koefisien Determinasi

\begin{tabular}{|l|r|r|r|r|}
\hline $\begin{array}{l}\text { Mod } \\
\text { el }\end{array}$ & $\mathrm{R}$ & $\begin{array}{r}\mathrm{R} \\
\text { Squar } \\
\mathrm{e}\end{array}$ & $\begin{array}{c}\text { Adjusted } \\
\mathrm{R} \text { Square }\end{array}$ & $\begin{array}{c}\text { Std. Error of the } \\
\text { Estimate }\end{array}$ \\
\hline 1 & $\begin{array}{r}, 853 \\
\mathrm{a}\end{array}$ &, 727 &, 669 & 1,0358483 \\
\hline
\end{tabular}

Sumber : Hasil Pengolahan Data (SPSS 21)

Berdasarkan tabel 3.6, terlihat bahwa nilai $r$ adalah 0,853 yang berarti bahwa terdapat korelasi yang sangat kuat antara nilai perusahaan dengan struktur modal, profitabilitas dan kebijakan dividen. Sementara koefisien determinasi (R Square) adalah 0,727, hal ini berarti 72,7 \% tinggi rendahnya nilai perusahaan dapat dijelaskan oleh struktur modal, profitabilitas dan kebijakan dividen. Sedangkan sisanya 27,3 $\%$ dijelaskan oleh faktor lainnya yang tidak dimasukkan dalam penelitian ini, misalnya Current Ratio (CR), Return On Assets (ROA) dan faktor lainnya yang tidak dijelaskan dalam penelitian ini.

\subsubsection{Uji Hipotesis}

1. Uji Simultan (Uji F)

Hasil uji $F$ dalam penelitian ini dapat disajikan dalam Tabel 3.7 sebagai berikut:

Tabel 3.7

Hasil Uji F

\begin{tabular}{|l|c|c|}
\hline Model & $F$ & \multicolumn{1}{|c|}{ Sig. } \\
\hline \multicolumn{1}{|c|}{$\begin{array}{l}\text { Regression } \\
1\end{array}$} & 12,435 &, $000^{\mathrm{b}}$ \\
Residual & & \\
Total & & \\
\hline
\end{tabular}

Sumber: Hasil Pengolahan Data SPSS 21 (2018)

Dari Tabel 3.7 terlihat bahwa nilai $F_{\text {hitung }}$ akan dibandingkan dengan $F_{\text {tabel. }}$ Tingkat signifikansi $5 \%$, dengan level of confidence $95 \%(=0,05)$ dan degree of 
freedom (n-k-1), dimana (n) adalah jumlah data dan $(k)$ adalah jumlah variabel independen. $\mathrm{df}=14$ dan $\mathrm{k}=3$, maka diperoleh $F_{\text {tabel }}$ sebesar 3,74. Berdasarkan tabel di atas diperoleh nilai $F_{\text {hitung }}$ sebesar 12,435 dan nilai ini lebih besar dari $F_{\text {tabel }}$ atau dapat dikatakan $12,435>3,74$ atau nilai signifikansi $(0,000)$ lebih kecil dari nilai $\alpha$ $(0,05)$, dapat dikatakan $0,000<0,05$ maka $\mathrm{H}_{0}$ ditolak. Hal ini berarti struktur modal, profitabilitas dan kebijakan dividen berpengaruh signifikan terhadap nilai perusahaan pada Sub Sektor Otomotif dan Komponen yang terdaftar di Bursa Efek Indonesia.

\section{Uji Parsial (Uji t)}

Hasil uji $t$ dalam penelitian ini dapat disajikan dalam Tabel 3.8 sebagai berikut:

Tabel 3.8

Hasil Uji t

\begin{tabular}{|c|c|c|}
\hline Model & $\mathrm{T}$ & Sig. \\
\hline (Constant) &,- 720 & ,483 \\
\hline LtDER & $-1,093$ & 293 \\
\hline ROE & 4,489 & ,001 \\
\hline DPR & 2,239 & ,042 \\
\hline
\end{tabular}
(2018)

Berdasarkan hasil uji Tabel 3.8, dapat diketahui variabel struktur modal mempunyai nilai $t_{\text {hitung }}$ sebesar $-1,093$ lebih kecil dari 2,14479 atau dapat dikatakan -1,093 < 2,14479 atau nilai signifikansi struktur modal $(0,293)$ lebih besar dari nilai $\alpha(0,05)$, dapat dikatakan $0,293>0,05$, maka $\mathrm{H}_{0}$ diterima atau dapat dikatakan struktur modal berpengaruh tidak signifikan terhadap nilai perusahaan pada Sub Sektor Otomotif dan Komponen yang terdaftar di Bursa Efek Indonesia tahun 2011-2016.

Variabel profitabilitas mempunyai nilai $t_{\text {hitung }}$ sebesar 4,489 lebih besar dari $t_{\text {tabel }}$ sebesar 2,14479 atau dapat dikatakan 4,489 $>2,14479$ atau nilai signifikansi profitabilitas $(0,001)$ lebih kecil dari nilai $\alpha(0,05)$, dapat dikatakan $0,001<0,05$, maka $\mathrm{H}_{0}$ ditolak atau dapat dikatakan profitabilitas berpengaruh signifikan terhadap nilai perusahaan pada Sub Sektor Otomotif dan Komponen yang terdaftar di Bursa Efek Indonesia tahun 2011-2016.

Variabel kebijakan dividen mempunyai nilai $t_{\text {hitung }}$ sebesar 2,239 lebih besar dari $t_{\text {tabel }}$ sebesar 2,14479 atau dapat dikatakan 2,239 $>2,14479$ atau nilai signifikansi kebijakan dividen $(0,042)$ lebih kecil dari nilai $\alpha(0,05)$, dapat dikatakan $0,042<0,05$, maka $\mathrm{H}_{0}$ ditolak atau dapat dikatakan kebijakan dividen berpengaruh signifikan terhadap nilai perusahaan pada Sub Sektor Otomotif dan Komponen yang terdaftar di Bursa Efek Indonesia tahun 2011-2016.

\subsection{Evaluasi}

\subsubsection{Evaluasi Struktur Modal Pada Perusahaan Sub Sektor Otomotif dan Komponen yang Terdaftar di Bursa Efek Indonesia}

Dari hasil penelitian menunjukkan bahwa struktur modal pada Perusahaan Sub Sektor Otomotif dan Komponen yang terdaftar di Bursa Efek Indonesia tahun 2011-2016 berfluktuasi dan cenderung mengalami penurunan. Hal ini disebabkan karena perusahaan lebih banyak menggunakan pendanaan dari pihak internal perusahaan dari pada pendanaan dari pihak eksternal perusahaan.Bagi setiap perusahaan, keputusan dalam pemilihan sumber dana merupakan hal yang penting karena dapat mempengaruhi struktur keuangan perusahaan dan kinerja perusahaan. Semakin tinggi hutang untuk membiayai operasional perusahaan dapat menurunkan nilai perusahaan dikarenakan dengan tingginya hutang maka beban yang ditanggung perusahaan juga semakin besar.

Oleh karena itu, sebaiknya perusahaan dapat menambah penggunaan pendanaan 
eksternal dengan mempertimbangkan struktur modal yang optimal, struktur modal yang optimal akan tercapai apabila berusaha mencari struktur modal yang menghasilkan keseimbangan antara risiko perusahaan dan pengembalian yang akan memaksimalkan harga saham. Harga saham yang maksimal dapat meningkatkan nilai perusahaan.

\subsubsection{Evaluasi Profitabilitas Pada Perusahaan Sub Sektor Otomotif dan Komponen yang Terdaftar di Bursa Efek Indonesia}

Hasil penelitian ini menunjukkan bahwa kondisi profitabilitas pada perusahaan Sub Sektor Otomotif dan Komponen yang terdaftar di Bursa Efek Indonesia periode 2011 - 2016 berfluktuasi dan cenderung menurun. Hal ini disebabkan karena lebih besarnya laba bersih setelah pajak yang digunakan dibandingkan dengan total ekuitas perusahaan.

Untuk meningkatkan profitabilitas, sebaiknya perusahaan dapat melakukan peningkatan pada penjualan seperti menaikkan kualitas produk yang dipasarkan dan meminimalisir biaya operasional perusahaan. Dengan begitu dapat meningkatkan laba perusahaan yang berdampak pada naiknya nilai perusahaan.

\subsubsection{Evaluasi Kebijakan Dividen Pada Perusahaan Sub Sektor Otomotif dan Komponen yang Terdaftar di Bursa Efek Indonesia \\ Dari hasil penelitian, dapat diketahui} bahwa kebijakan dividen pada perusahaan Sub Sektor Otomotif dan Komponen yang terdaftar di Bursa Efek Indonesia periode 2011 - 2016 berfluktuasi dan cenderung meningkat. Hal ini disebabkan oleh laba per lembar saham dan dividen sama - sama mengalami penurunan, akan tetapi penurunan laba per lembar saham lebih besar dibandingkan dividen.

Sebaiknya perusahaan juga

keluar dengan meminimalisir biaya operasional perusahaan yang digunakan sebagai investasi sehingga pembagian dividen dapat tetap meningkat. Dengan meningkatnya pembagian dividen maka dapat meningkatkan kemakmuran para investor.

\subsubsection{Evaluasi Nilai Perusahaan Pada Perusahaan Sub Sektor Otomotif dan Komponen yang Terdaftar di Bursa Efek Indonesia}

Hasil penelitian ini menunjukkan bahwa nilai perusahaan pada Perusahaan Sub Sektor Otomotif dan Komponen yang terdaftar di Bursa Efek Indonesia periode 2011-2016 berfluktuasi dan cenderung stabil. Hal ini disebabkan karena nilai buku per lembar saham yang meningkat diikuti dengan peningkatan harga saham. Hal ini dapat dilihat nilai perusahaan pada tahun 2011 adalah sebesar 2,190 sedangkan nilai perusahaan pada tahun 2016 adalah sebesar 2,710 . Nilai perusahaan yang stabil disebabkan oleh meningkatnya harga saham dan nilai buku tidak terlalu tinggi.

Untuk meningkatkan nilai perusahaan, sebaiknya perusahaan lebih maksimal dalam mengelola kinerja keuangan perusahaan. Perusahaan dengan kinerja yang baik dapat memperoleh laba yang maksimal serta dapat membagikan dividen yang cukup tinggi kepada para investor dan harga saham dapat meningkat.

\section{KESIMPULAN DAN SARAN}

4.1. Kesimpulan

Dari hasil pengujian analisis dan hipotesis yang telah dibahas pada bab sebelumnya, maka penulis menarik beberapa kesimpulan sebagai berikut:

1. Rata-rata struktur modal pada Perusahaan Sub Sektor Otomotif dan Komponen yang terdaftar di Bursa Efek Indonesia periode 2011-2016 berfluktuasi dan cenderung mengalami penurunan. Hal ini disebabkan karena 
perusahaan lebih banyak menggunakan pendanaan dari pihak internal perusahaan dari pada pendanaan dari pihak eksternal perusahaan. Hal ini bisa dilihat dari perkembangan total ekuitas yang meningkat setiap tahunnya.

2. Rata-rata profitabilitas pada Perusahaan Sub Sektor Otomotif dan Komponen yang terdaftar di Bursa Efek Indonesia periode 2011-2016 berfluktuasi dan cenderung menurun. Hal ini disebabkan karena lebih besarnya laba bersih setelah pajak yang digunakan dibandingkan dengan total ekuitas perusahaan.

3. Rata-rata kebijakan dividen pada Perusahaan Sub Sektor Otomotif dan Komponen yang terdaftar di Bursa Efek Indonesia periode 2011-2016 berfluktuasi dan cenderung meningkat. Hal ini disebabkan oleh laba per lembar saham dan dividen sama - sama mengalami penurunan, akan tetapi penurunan laba per lembar saham lebih besar dibandingkan dividen.

4. Rata-rata nilai perusahaan pada pada Perusahaan Sub Sektor Otomotif dan Komponen yang terdaftar di Bursa Efek Indonesia periode 2011-2016 berfluktuasi dan cenderung stabil. Hal ini disebabkan karena nilai buku per lembar saham yang meningkat diikuti dengan peningkatan harga saham.

5. Dari hasil pengujian regresi linier berganda diketahui bahwa struktur modal berpengaruh negatif sedangkan profitabilitas dan kebijakan dividen berpengaruh positif terhadap nilai perusahaan pada perusahaan Otomotif dan Komponen yang terdaftar di Bursa Efek Indonesia periode 2011-2016.

6. Melalui analisis koefisien korelasi dan determinasi dapat diketahui bahwa terdapat korelasi yang sangat kuat antara nilai perusahaan dengan struktur modal, profitabilitas dan kebijakan dividen. Sementara koefisien determinasi menunjukkan bahwa nilai perusahaan lebih banyak dipengaruhi oleh struktur modal, profitabilitas dan kebijakan dividen, sedangkan sisanya dijelaskan oleh faktor lainnya yang tidak dimasukkan dalam penelitian ini, misalnya Current Ratio (CR), Return On Assets (ROA) dan faktor lainnya yang tidak dijelaskan dalam penelitian ini.

7. Dari hasil uji F dapat disimpulkan bahwa struktur modal, profitabilitas dan kebijakan dividen berpengaruh signifikan terhadap nilai perusahaan pada Sub Sektor Otomotif dan Komponen yang terdaftar di Bursa Efek Indonesia.

8. Dari hasil uji t dapat disimpulkan bahwa struktur modal berpengaruh tidak signifikan sedangkan profitabilitas dan kebijakan dividen berpengaruh signifikan terhadap nilai perusahaan pada Sub Sektor Otomotif dan Komponen yang terdaftar di Bursa Efek Indonesia.

\subsection{Saran}

Berdasarkan kesimpulan dan hasil penelitian di atas, maka penulis memberikan beberapa saran yaitu sebagai berikut:

1. Sebaiknya perusahaan dapat menambah penggunaan pendanaan eksternal dengan mempertimbangkan struktur modal yang optimal, struktur modal yang optimal akan tercapai apabila berusaha mencari struktur modal yang menghasilkan keseimbangan antara risiko dan pengembalian yang akan memaksimalkan harga saham. Harga saham yang maksimal dapat meningkatkan nilai perusahaan.

2. Sebaiknya perusahaan dapat melakukan peningkatan pada penjualan seperti menaikkan kualitas produk yang dipasarkan dan meminimalisir biaya operasional perusahaan. Dengan begitu dapat meningkatkan laba perusahaan 
yang berdampak pada naiknya nilai perusahaan.

3. Sebaiknya perusahaan juga memperhatikan kebijakan aliran arus kas keluar dengan meminimalisir biaya operasional perusahaan yang digunakan sebagai investasi sehingga pembagian dividen dapat tetap meningkat. Dengan meningkatnya pembagian dividen maka dapat meningkatkan kemakmuran para investor.

4. Sebaiknya perusahaan lebih maksimal dalam mengelola kinerja keuangan perusahaan. Perusahaan dengan kinerja yang baik dapat memperoleh laba yang maksimal serta dapat membagikan dividen yang cukup tinggi kepada para investor dan harga saham dapat meningkat.

\section{DAFTAR PUSTAKA}

Astuti, Dewi. 2004. Akuntansi Keuangan Menengah. Jakarta: Salemba Empat.

Brigham, Eugene F, dan Joel F. Houston. 2001. Manajemen Keuangan. Buku 1. Edisi VIII. Jakarta: PT Gelora Aksara Pratama.

2009. Dasar-dasar Manajemen

Keuangan. Buku 1. Edisi XI. Jakarta: Salemba Empat.

2010. Dasar-dasar Manajemen

Keuangan. Buku 1. Edisi XI. Jakarta: Salemba Empat.
Horngren T. Charles, Walter T. Thomas Jr. 2007. Akuntansi. Edisi VII, Jilid 1. Jakarta: Erlangga.

Keown, et. al. 2004. Manajemen Keuangan: Prinsip-prinsip Dasar dan Aplikasi. Edisi IX, Jilid I. Jakarta: PT Indeks Kelompok Gramedia.

Martani, Dwi, dkk. 2012. Akuntansi Keuangan Menengah Berbasis PSAK. Buku 1. Jakarta: Salemba Empat.

Mursyidi. 2010. Akuntansi Dasar. Bogor: Ghalia Indonesia.

Riyanto, Bambang. 2009. Dasar-dasar Pembelanjaan Perusahaan. Edisi Keempat. Yogyakarta: BPFE.

Rudianto. 2009. Pengantar Akuntansi. Jakarta: PT Glora Aksara Pratama.

Subramanyam, K. R dan John J. Wild. 2010. Analisis Laporan Keuangan. Edisi X. Jakarta: Salemba Empat.

Sudana, I Made. 2011. Manajemen Keuangan Perusahaan Teori dan Praktik. Jakarta: Erlangga.

Weygandt, Jerry J., Donald E. Kieso., dan Paul D. Kimmel. 2007. Accounting Principles. Edisi 7. Jakarta: Salemba Empat. 